\title{
Analysis of Socio-Economic Impacts of Tourism Development in Komodo National Park, East Nusa Tenggara (A Case Study of Rinca Island and Komodo Island)
}

\author{
Mona Erythrea Nur Islami ${ }^{1}$, Diah Enggarwati ${ }^{2}$, Arif Dwi Saputra ${ }^{3}$ \\ \{mona234sc@gmail.com\}
}

AMPTA Tourism Institute, Yogyakarta, Indonesia ${ }^{123}$

\begin{abstract}
In Indonesia, tourism development is not only focused on the islands of Java and Bali, but also in eastern Indonesia, such as in the East Nusa Tenggara. This research aims to identify the change in the lives of local communities from a socio-economic approach. This is a qualitative research which the data were collected through in-depth interviews, observation, and documentation. The results showed that tourism activities on Rinca Island have not been felt yet by Rinca Island residents since only a few people have switched jobs in the tourism sector. From the structure of livelihoods point of view, there is no change as most people on Rinca Island are still working as fishermen. Meanwhile, the socio-economic impacts of the people on Komodo Island are different from Rinca Island. On Komodo Island, the most visible change is in the livelihood structure where the current population change their fisheries activities to a tourism work. Income from changing jobs to the tourism sector can improve the welfare of local communities. From a social approach, the positive impact of tourism development on Rinca Island and Komodo Island is able to increase local community participation. Although the impact of tourism felt by the people on Komodo Island and Rinca Island is different, the hospitality of the people in receiving tourists on the two islands has not changed.
\end{abstract}

Keywords: socio-economic impacts; Komodo National Park; East Nusa Tenggara

\section{Introduction}

As a tool, tourism is a good way to speed up development in Indonesia. The development of tourism development at this time is not only focused on the islands of Java and Bali, but also has led to tourism development in Eastern Indonesia. Especially after the discourse on environmental preservation and looking for for cultural experiences increased (Brauchler\&Erb in the TOR of the Unbraw National Culture Seminar, 2019). Some experts said that the development of Eastern Indonesia through tourism is the most appropriate way because beside lack of resources, it also has natural and cultural beauty (Cole, 2008). Komodo National Park data shows an increase in tourist visits during October, November and December 2018. In October 2018, the number of tourist visits reached 159,674 people. In November 2018, the number of tourist visits reached 168,506 people. In December 2018, the number of tourist visits reached 176,830 people (Komodo National Park data, 2018). Komodo National Park is not only popular for the existence of the Komodo dragon as a protected endangered animal, 
but also famous for its natural beauty. This is evidenced by UNESCO's recognition in 1991 of Komodo National Park as a world heritage site.

Tourism with all the aspects of life related to it will get the consequences between two or more different cultures, such as the culture of the tourists (guest) and the culture in that society around the place (host) of tourism destination (Pitana, 2005). The different cultures which have a contact will make an impact on all aspects of life, especially for local people who live around the tourism destination. There are two characteristics of the impact, that is the impact which have positive characteristic or is known as manifestation and negative impact or it is called by latency. Manifestation has a desirable expectation tendency from a social process that occurs while latency is an unexpected form, but naturally always participate or appears (SoerjonoSoekanto in Miswanto, 2018: 48).

In the essence, there are four main areas which are influenced by tourism development efforts, such as economic, social, cultural and environmental. The economic impact will be the main attention, concern for the socio-cultural impact that will come later. The transfer of people's occupation will affect to the changes socio-cultural system in society. When we observe on a micro-level, the positive impact of tourism development from an economic aspect is able to grow the community's economy through creating new occupation for local people, their income and standard of living will increase, and increasing informal sector businesses. But on the other hand, it also creates underage workers and hawkers who disturb the tourists. The social impacts which can be observed due to tourism activities such as the changes of social values in society and social stratification. Meanwhile, the cultural impacts which can be observed include the commercialization of culture, changes in the lifestyle, and society traditions.

Currently, rural tourism issue is being popular and discussed. Rural tourism can be an introduction to sustainable development. Efforts to develop rural tourism are also being carried out in Komodo National Park by utilizing natural and cultural potential, as well as involving local communities. Rural tourism in the Komodo National Park area is expected to be a community-based tourism empowerment (community-based tourism). This research focuses on the dynamics of the socio-cultural life of local communities living in the Komodo National Park area with the existence of rural tourism activities. Economic, social and cultural impacts need to be known to see the extent to which tourism and tourist arrivals will influence the socio-cultural conditions of the local community.

\section{Methodology}

This research was conducted in Komodo National Park, particularly on Komodo Island and Rinca Island. This location was chosen considering the rapid development of tourism there. The research method used in this research is qualitative research methods. While the data collection technique such as observation, in-depth interviews, and documentation. The informants in this study were taken by purposively, the respondents are people who work in the tourism sector. They are naturalist guides, homestay owners, souvenir sellers, tour boat owners, and shop owners.

This study use a descriptive-interpretative analysis method with the following steps: (1) selecting relevant documents / data; (2) making objective notes, such as classifying and reducing answers; (3) making reflective notes, which is interpreting in relation to objective notes; (4) summarize the data; (5) triangulation, namely checking the correctness of the data 
by concluding the double data obtained in three ways: (a) extending the time of field observations with the aim of matching the data that has been written with field data, (b) matching data that has been written with ask the informants again, and (c) match the data that has been written with the library sources. Data analysis and processing were carried out in two stages, namely: first, at the same time as data collection activities; the second is done after data collection ends.

\section{Result and Discussion}

We carried data collection in this study on two large islands in the Komodo National Park (KNP), there are Rinca Island and Padar Island. The results on the two islands related to the economic and socio-cultural impacts of tourism development in the KNP area.

\subsection{A Fairy Tale About Komodo Dragon}

Once upon a time, there was a girl from heaven who came down to earth. Her name is Putri Naga Komodo. One day, Putri Naga Komodo met a young Komodo man (a young man who lives on Komodo Island). They greet each other and ask a question. The young man offered a place to stay to Putri Naga Komodo, and they ended up living together. After that, they loved each other and got married on their own terms. Putri Naga Komodo was pregnant and gave birth to a baby and an egg. Putri Naga Komodo secretly hide the egg in a place where no one knew about it. Few times later, the egg hatched, and it turned out to be Komodo that came out from the egg. Putri Naga Komodo continues to take care for the Komodo dragon like a child with no one know about it. One day, they were hunting a deer in the forest. When the deer was shot by an arrow and fell to the ground, Komodo came to that. Anak Putri Naga Komodo raised an arrow and prepared to shoot the Komodo dragons. Putri Naga Komodo hold him back and said: "Don't!". a child asked his mother: "Why mom?", Then Putri Naga Komodo replied: "That is your brother." Since then, Komodo dragons have lived side by side with humans.

In the community there is a myth that whoever hurts or kills a Komodo, there will be offspring, whether their children, grandchildren, great-grandchildren, and so on, who will be bitten by the Komodo dragon. They believe that Komodo will take revenge on humans who killed them.

\subsection{Rinca Island: At a Glance}

Pasir Panjang Village is a village in Komodo District, West Manggarai Regency, East Nusa Tenggara Province. The area of Pasir Panjang Village is 19,625 ha. Pasir Panjang village has a population of 1,634 people with a proportion of 889 males and 755 females. $100 \%$ of the population in Pasir Panjang are Muslims. Pasir Panjang village is better known as Rinca Village because of the position is on Rinca Island. Rinca Village comprises "Sepotong Bajo" and "Sepotong Komodo". Sepotong Bajo is inhabited by the majority of ethnic Bajo, while Sepotong Komodo is inhabited by the majority of ethnic Komodo dragons. The boundaries of Sepotong Bajo and Sepotong Komodo are a mosque. Even though Rinca Island is one of the tourism destinations in Komodo National Park, $98 \%$ of the population are fisherman, while the remaining $2 \%$ become naturalist guides, teachers, and other livelihoods. Tourist visit to Rinca 
Village is still in fluctuating conditions. We can see tourist visit to Rinca Village in 2019 in the table below.

Table 1. Tourists in Rinca Village Visits in 2019

\begin{tabular}{cc}
\hline Month & Total of Tourists \\
\hline January & 71 \\
February & 106 \\
March & 75 \\
April & 90 \\
May & 60 \\
June & 125 \\
July & 215 \\
August & 341 \\
September & 228 \\
October & 132 \\
November & 94 \\
December & 77 \\
\hline Total & $\mathbf{1 . 6 1 4}$
\end{tabular}

\subsection{Attractions, Amenities, and Tourism Accessibility of Rinca Village}

Attractions. There are several tourist attractions in Rinca Village, such as Kalong Cave, Batu Balok, Strawberry Island, Kalong Island, Loh Buaya, and Manca Dance. Kalong Cave is a cave inhabited by many bats. Batu Balok is a place in the forest where a stone is in the shape of a block, like a wooden block that overlaps with each other. Strawberry Island has rocks it is red like strawberry, so it called by Strawberry Island. Kalong Island is one of the best islands to enjoy the sunset in Komodo National Park. On this island, tourists can see hundreds of bats coming out and flying when the sun begins to set. In Loh Buaya, tourists can see mangrove forests, savanna, and wildlife such as Komodo dragons, Timor deer, wild buffalo, long-tailed monkeys, wild horses, and various types of birds. Manca dance is a traditional dance from Rinca. The word "Manca" comes from Bajo language which means "silat" or traditional martial art. Manca dance is a combination of traditional dance and martial art.

\section{Amenities}

The amenities (supporting facilities) which found in Rinca Village are a homestay, a souvenir shop, a dock, a ticket booth, a hand washing area, a welcome gate, a shop, electricity from State Electricity Company (PLN), elementary school, and junior high school. There are two homestays in Rinca Village, such as Rinca Homestay and Homestay Putri Tunggal. The homestay rate per day is IDR 250,000 - IDR 300,000 for foreigner, while for domestic tourists you can bid up to IDR 150,000 per day. Meanwhile, there is only one souvenir shop, which sells various kinds of accessories, such as: pearl necklaces and bracelets, seashell necklaces, bahar root bracelets, seashell bowls and plates, Manta Pari necklaces, Komodo statues, and Chicken Ceker Cake molds.

\section{Accessibility}

Rinca Village can be reached using water transportation, it is a motorcycle taxi from the Labuan Bajo pier. The fare is IDR 20,000 per person and takes about 1.5 - 2 hours of travel. 
The schedule for the rent boat from Labuan Bajo - Rinca Village is the fastest at 12.00 WITA or after midday. Meanwhile, from Rinca Village - Labuan Bajo the schedule is 07.00 WITA. For those who visit Rinca Village for tourist purposes, they usually use a tour boat that chartered from Labuan Bajo.

\subsection{The Economic Impacts of Tourism in Rinca Village}

There is no significant change in Rinca Village for tourism. The obvious impact is the improvement of infrastructure in Rinca Village, such as State Electricity Company (PLN) electricity, so the Rinca's society can use electricity all day long. In addition, piers, towers, and schools have also been built to become better because tourism is increasingly becoming a trend. The impact of tourism on the economic conditions of the people of Rinca Village is only felt by people who work as business actors in the tourism sector. In the past, almost all of the people of Rinca Village worked as fishermen. However, currently, there are transformation in their livelihoods from fisherman to be entrepreneurs in the tourism sector, such as become a naturalist guide, homestay owner, souvenir seller, and tour boat owner.

Even so, not many people are interested in changing their livelihoods in the tourism sector. According to Mr. Alwi, the majority of society of Rinca Village still choose to work as fishermen because they feel that tourism has not provided many benefits for them (Interview, 18 September 2020).

\section{Naturalist Guide}

Naturalist guides to guide special tours of Komodo. Many people call him "ranger". This concept is misleading because the ranger is actually the forest ranger from NKP. However, because they united the naturalist guides in it, people called them ranger. There is a code of ethics when serving as a naturalist guide, including: (1) not wearing sunglasses, unless it is hot and in the field; (2) must not to be close to guests (keep a distance from guests); (3) when explaining to guests, they must not be in a state of walking and the voice must be loud; and (4) must always carry a stick with two ends. Naturalist guides are a risky job, so they have to apply insurance and Institution of Social Security employment (BPJS Ketenagakerjaan). 70\% of naturalist guides come from local people. The remaining $30 \%$ is from outside, such as Ruteng, Bajawa, Labuan Bajo, and so on. $80 \%$ of Rinca people still focus on fisherman. $20 \%$ of Rinca people switch their job to be tourism sector because of language barriers. They don't speak English well. Especially at this time, being a naturalist guide requires at least a high school diploma.

\section{Homestay Owner}

One of the homestay owners in Rinca Village is H. Ishaka (Aji). Aji is the owner of Rinca Homestay which started in 2015. In 2018, Aji received help to build a 4-bedroom homestay. The homestay rates per day is IDR 250,000 for foreign tourists, while domestic tourists can bid up to IDR 150,000 per day. This rate includes meals 3 times a day. The facilities at this homestay are mattresses with mosquito nets, while there is only one sharing bathroom considering the difficulty of fresh water in Rinca Village. Not every month there are guests, either at Rinca Homestay or Homestay Putri Tunggal.

\section{Souvenir Seller}

Aji is the only trainer and souvenir / accessories seller in Rinca Village. The souvenirs that Aji sells are pearl necklaces and bracelets, seashell necklaces, bahar root bracelets, 
seashell bowls and plates, Manta Pari necklaces, Komodo statues, and chicken claw cake molds. They adjust the price of the souvenirs according to tourists who come to Rinca Village. Foreign tourists will be pegged at a higher price than domestic tourists because foreign tourists will think the higher the price of the goods being offered, for better quality of the goods. Souvenir's price is around IDR 100,000 - IDR 500,000. Aji's income from selling souvenirs is uncertain every month, depending on the tourists who come to buy it. Before the pandemic, Aji's average income was around IDR 1,000,000 - IDR 2,000,000 per month.

Tour Boat Owners. A tourist boat is a boat used for tourist, they rent to tourists who come to KNP. In Rinca Village, there are 3 persons who are the owner of a tour boat. One of them is Pak Safarula Rogi, who is called by Pak Rula. Before working in the tourism sector, Pak Rula was a fisherman. Pak Rula became the owner of a tour boat in 2019. The facilities on Pak Rula's tour boat are 2 rooms where 1 room is for 4 people, air conditioning, fan, bathroom with shower. Pak Rula's boat capacity is for 8 guests. Mr. Rula follows the guest schedule, where the destination is also chosen by the guests and the guides.

The popular destinations are Long Beach, Padar Island, Kenawa Island, Manta Point, Kelor Island, Loh Buaya, and others. The trip usually for full day trip for 4 locations, such as Long Beach, Padar Island, Kenawa Island, and Manta Point. There is variation prices offered and they can also negotiate. Usually, a 3-day 2-night trip for 2 persons costs IDR 6,000,000; 3 days 2 nights trip for 8 persons is IDR 13,000,000; 2 days 1 night trip for 8 persons is IDR 11,000,000 - IDR 12,000,000; and a full day trip for 8 persons is IDR 3,500,000. Pak Rula's income has increased after becoming a tourist boat owner. Pak Rula's income during high season is around Rp. 100,000,000 per month, while income during low season is around Rp. 20,000,000 - Rp. 30,000,000 per month.

\subsection{The Socio-Cultural Impacts of Tourism in Rinca Village}

Tourism has had little impact on the people of Rinca Village. But at least tourism has contributed to the socio-cultural conditions of the people of Rinca Village. The effects of tourism on the socio-cultural conditions of the people of Rinca Village is the presence of a new social organization, such as Pokdarwis KOMPAS, language acculturation, opening of new networks (relationships), and improving the quality of human resources (HR).

\footnotetext{
A New Social Organization: Pokdarwis KOMPAS

KOMPAS is an acronym for the Tourism Care Community Group, which is a tourism awareness group in Rinca Village. KOMPAS was initiated in 2017 by Mr. Alwi and Mr. Mustafa, and started running in February 2018. The KOMPAS program is related to tourism. Currently KOMPAS is selling tour packages in Rinca Village, namely Batu Balok, Goa Kalong, and village tours. The fare for traveling around the village is Rp.10,000, they will pay it at the ticketing counter to enter the village. The fare to Batu Balok and Goa Kalong is IDR 40,000 per person per location. Guide service is IDR 20,000/guide. One guide is responsible for a group of 3-5 tourists. KOMPAS's work program was not maximal because of a lack of knowledge related to tourism (limited human resources). In addition, there is friction between KOMPAS and BUMDES where BUMDES wants to take over and manage KOMPAS. Meanwhile, KOMPAS was formed on the initiative of groups outside and before BUMDES. To date, neither party considers a suitable solution.
} 


\section{The Existence of Language Acculturation}

Language is an element of universal culture. Language means: (1) an arbitrary sound symbol system, it is used by members of a society to cooperate, interact and identify themselves; (2) good (verbal) conversation; good manners; politeness. The presence of tourism in Rinca Village has slightly changed people how to communication. The people of Rinca Village often to speak Indonesian, especially to tourists. In daily life, most of the people use local languages. Using Indonesian is actually not only influenced by the existence of tourism, but also because in Rinca Village there are several ethnic groups with different languages, including Bajo, Komodo and Bima, so they use Indonesian to communicate. Besides use Indonesian, people of Rinca Village are familiar with foreign terms, such as homestay, tracking, naturalist guide, ranger, and others. These terms in English are often spoken by the people of Rinca Village, but they do not realize that the language does not come from them. These terms come from tourism that has been acculturated in the community.

\section{The Opening of New Networks (Relationships)}

Tourism activities in TNK can provide wider job opportunities, as well as open new networks (relationships). The existence of tourism makes people interact with other people, thus creating new networks. The opportunity to interact with other people is open widely, especially for those who work in the tourism sector. By having an extensive network, cooperation can be built easily and will have their own benefits. For example, to promote their tour boat, or even sell souvenirs outside KNP, both domestically and abroad.

\section{Increasing the Quality of Human Resources}

Since the existence of tourism, both the TNK and the local government have programs to improve the quality of human resources in the KNP area, including in Rinca Village. These programs are realized in the form of training and socialization related to tourism. The training that has been carried out in Rinca Village includes naturalist guide training, plastic waste recycling craft training, homestay training, and so on. With the training and socialization, the people of Rinca Village start know about new things. Not only from the TNK and the local government, KKN students in Rinca Village also contributed to improving the quality of HR in Rinca Village through their work program.

\subsection{Rinca Village Conditions During the COVID-19 Pandemic}

Since there is COVID-19 pandemic, tourism activities in KNP is paralysis. This resulted in economic shocks for tourism actors in Rinca Village, such as: naturalist guides, homestay owners, tour boat owners, souvenir sellers, and even Pokdarwis KOMPAS. Meanwhile, those who do not work in the tourism sector are not affected because they are still fishing as usual. Those who depend on the tourism sector eventually return to fishing. They go to sea and catch fish to make ends meet. Not only returning to being a fisherman, some have even shifted their steering wheel selling fresh water since the pandemic and as a result of the lack of tourism activities. Since there is COVID-19 pandemic in Indonesia, the government has promoted aggressively the Clean and Healthy Behavior movement, one of them is washing hands with soap. In connection with this, Rinca Village as a tourist destination received help in the form of facilities for washing hands and a place for soap.

However, this facility only uses during the early days of the pandemic and looks neglected. Due to the difficulty of getting fresh water in Rinca Village and the lack of stock of hand washing soap. Apart from washing hands with soap, the government also appealed to all 
people to keep their distance and wear masks. However, this does not appear to be the case in Rinca Village. You can see people talking without social distancing and wearing masks. They only use masks when they are going to Labuan Bajo because the local government requires everyone to wear masks in the Labuan Bajo area. If They do not wear a mask, they will get fined a certain amount of money. The absence of a COVID-19 case has made people feel safe and carry out activities like normal days before the pandemic.

\subsection{Komodo Island: At a Glance}

Komodo Island is the western of East Nusa Tenggara Province, it is bordering to West Nusa Tenggara Province. In 1910, the Dutch named this island with the nickname Komodo Island. This story begins with Lieutenant Steyn van Hens Broek who tried to prove reports of Dutch troops about the existence of a large animal resembling a dragon on the island. Steyn then killed a Komodo dragon and took the documentation to the Museum and Botanical Garden in Bogor for research. On Komodo Island, Komodo dragons live and breed well. Until August 2009, there were around 1,300 Komodo dragons on this island.

Komodo Village is the only village on Komodo Island. This village area is $34,762 \mathrm{~km} 2$, it covers $35.83 \%$ of the area of Komodo sub-district. The people of Komodo Village are the Atamodo tribe. They have a culture in the form of Arugele dance, ario singing, "pencak silat", and "kolkamba". Most of the people of Komodo Village make their living in the tourism sector, but a small proportion still work as fisherman. Tourism activities in the TNK have significant economic and social effects on the lives of local communities in Komodo Village. In 2011, Komodo Island becomes the Seven Wonders of the World, and from that time the local community developed creativity, such as sculpting statues and becoming tour guides.

\subsection{Attraction, Amenity, and Tourism Accessibility of Komodo Village}

\section{Attractions}

The tourist attractions in Komodo Village such as the sunrise in Komodo Village, local community culture (traditional dances), the myth that the Komodo dragon people is the twin of the Komodo dragon, tracking in the hills of Komodo Village, and daily activities of the people of Komodo Village. Previously, there was an Ora school activity (an English-based natural school for tourism) which is the activity was carried out on the hill of Komodo Village and previously it became a tourist attraction for tourists. On Komodo Island, Pink Beach and Loh Liang as the major tourist attractions also.

\section{Amenities}

The amenities that we can find in Komodo Village are mosques, food and drink stalls, souvenir shops, homestays, Wi-Fi, Village Offices, early childhood education, elementary school, junior high school, Atamodo Reading Park, and supporting community health centers. In Komodo Village there are 3 mosques. It because of the people of Komodo Village, which number 1,869 people, embrace Islam, so that Islamic culture is very thick in this village. Based on data from the West Manggarai Regency Tourism and Culture Office, Komodo Village has 50 homestays, but only 10 of them often receive guests.

\section{Accessibility}

Transportation that can reach to Komodo Village is water transportation. The people of Komodo Village usually use a motorcycle taxi as their transportation to Labuan Bajo. From 
Labuan Bajo to Komodo Village is about 5 hours. Usually departing from Labuan Bajo around 11.00 WITA and arriving at Komodo Village at 13.00 WITA at a cost of IDR 30,000 / person for one way. This motorcycle taxi boat only runs every two days, either from Komodo Village - Labuan Bajo or from Labuan Bajo - Komodo Village.

\subsection{The Economic Impacts of Tourism in Komodo Village}

Tourism development in Komodo Village has a big impact on the economic aspect. The positive impact of tourism development in Komodo Village has led to changes in the livelihood structure of the population from fisherman to the tourism sector, such as becoming naturalist guides, homestay owners, souvenir sellers, boat owners, and opening shops. Income from jobs in the tourism sector can improve the welfare of local communities. Apart from positive effects, tourism development in Komodo Village also has a negative impact, namely an increase in the price of goods.

\section{Naturalist Guide}

One of the naturalist guides from Komodo Village is Pak Hamnor. He works as a naturalist guide is influenced to the welfare of his life. Income as a naturalist guide is considered will be more than a fisherman. His income is increasing along with the increasing number of tourist visits.

\section{Homestay Owner}

One of the homestay owners in Komodo Village is H. Salim. Since 2013 until now, this homestay has only relied on the offline mouth to mouth promotion system. In 2013, the homestay rate is IDR 200,000 for a room including two meals. They serve meals in a buffet. In 2014, the price for the homestay is IDR 300,000 for a room including two meals.

\section{Souvenir Seller}

One of the souvenir sellers in Komodo Village is Pak Yusup. Previously, Pak Yusup was a fisherman. Pak Yusup's income was greater when he was involved in the tourism sector than when he was a fisherman. Types of souvenirs sold include: Komodo statues, miniature ships, necklaces, earrings, and pearl bracelets. The Komodo statue was made by themselves in collaboration with the Komodo Village sculptor, while the other souvenirs were imported from outside.

\section{Tour Boat Owners}

Pak Yusup's brother is one of the tour boat owners. Meanwhile, Pak Yusup is the manager. The tour boat promotion system is still offline. The tour packages offered is diverse, such as Padar Island, Loh Sebita, and Gili Lawa. Tourists who often use the services of this tour boat are mostly backpackers who stay at the Komodo Village homestay. The facilities on this ship are buoys and toilets.

\section{Warung Owners}

One of the owners of a food stall in Komodo Village is Mrs. Dahlia. Mrs. Dahlia's welfare had been increasing as her income as a shop owner in Komodo Village. The daily income is around IDR 1,000,000 - IDR 2,000,000. This is influenced by the number of tourists who come and the selling price of food and drinks soaring. The price of food for domestic tourists is between IDR 25,000 - IDR 50,000, while the price of food for foreign tourists is 
between IDR 50,000 - IDR 100,000. This difference price become an agreement with all food and beverage sellers in Desa Komodo.

\subsection{The Sosio-Cultural Impacts of Tourism in Komodo Village}

From the socio-cultural aspect, the positive impact of tourism development in Komodo Village is able to increase local community participation. They formed several social organizations engaged in tourism to accommodate the activities of residents in Komodo Village, such as Pokdarwis, cooperatives, community cultivators of tourism, and the Komodo Island student association. Pokdarwis Desa Komodo was established in February 2020. This tourism awareness group change the name from previously called by KOGETA (Community of Tourism Cultivators) then in to Pokdarwis under the direction of the West Manggarai Regency Tourism and Culture Office. This Pokdarwis was formed based on the concern and love of the young generation of Komodo Village for the village, community, environment, and tourism potential as well as the cultural wealth that exists on Komodo Island. So far, Pokdarwis Komodo Village has produced an activity, such as a handicraft business and a garbage house. By working with a group of housewives, waste in Komodo Village can be handled properly.

Apart from positive impacts, it turns out that tourism development also has negative effects in the socio-cultural aspects. The existence of tourism development has resulted in conflicts between the people of Komodo Village and the KNP, such as the plan to close temporarily Komodo Island for rehabilitation and the prohibition of selling in Loh Liang as a tourist area. However, this conflict can be resolved properly.

\subsection{Condition of Komodo Island During the COVID-19 Pandemic}

The COVID-19 pandemic paralyzes the tourism sector in the KNP area, including in Komodo Village. In fact, compared to Rinca Village, the impact felt by the people of Desa Komodo is much greater. This is because most of the people of Komodo Village have switched jobs in the tourism sector, so that the cessation of tourism has also stopped their economy. Since the outbreak of COVID-19, the income of the people of Komodo Village has shrunk and fallen. They do not want the TNK area to be closed and hope the pandemic will be end soon so that their economic conditions will return to be normal. Tourism activities in Loh Liang during a pandemic followed a fairly strict health protocol where incoming tourists were prohibited from coming into direct contact with a naturalist guide. They direct Tourists to wash their hands before entering tourist sites.

\section{Conclusion}

Tourism development had a major impact on the community in Komodo Village, but this impact is not very visible in Rinca Village. Tourism activities on Komodo Island provide positive and negative changes to the socio-economic life of the community. From an economic aspect, the positive impact of tourism development on Komodo Island has led to changes in the livelihood structure of the population from fisherman to the tourism sector, such as becoming naturalist guides, homestay owners, souvenir sellers, boat owners, and opening shops. 
Meanwhile, the negative impact is an increase in the price of goods. From the social aspect, the positive impact of tourism development on Komodo Island is they can increase local community participation through organizations such as POKDARWIS, cooperatives, community cultivators of tourism, and the Komodo Island student association. But on the other side, it has also triggered conflict between residents on Komodo Island and the Komodo National Park. Whereas on Rinca Island, the positive impact from this aspect has not been felt because only a few residents have switched jobs to the tourism sector, such as becoming naturalist guides, souvenir sellers, renting out homestays, and renting out tourist boats.

When viewed from the structure of the people's livelihoods, there has been no change in the structure of their livelihoods because most of the people on Rinca Island are still working as fisherman. From the social aspect, the positive impact of tourism development on Rinca Island is the formation of social organizations to accommodate tourism activities on Rinca Island, such as POKDARWIS KOMPAS, BUMDES, and OPR student organizations; improving the quality of human resources. Meanwhile, the negative impact that arises is the emergence of internal conflicts between tourism administrators and village administrators in terms of tourism management, thus hampering the progress of tourism on Rinca Island.

\section{References}

[1] A, Yoeti, Oka. 1996. Pengantar Ilmu Pariwisata. Bandung: Angkasa.

[2] Alister, Mathieson dan Geoffrey Wall. 1982. Tourism Economy Physical and Social Impact. New York: Longman Group.

[3] Cohen, Erik. 1984. The Sociology of Tourism: Approaches, Issues, and Finding. California: Annual Review of Sociology, Vol. 10.

[4] Cole, S. 2008. Living in Hope: Tourism and poverty alleviation in Flores. University of the West of England.

[5] Ernawati, Ni Made. 2011. Pengaruh Pariwisata Terhadap Kehidupan Sosial Budaya Pesisir di Kawasan Taman Nasional Bali Barat dan Taman Wisata Pulau Menjangan. Jurnal Sabda, Volume 6, Nomor 1, April 2011: 69-74 ISSN 1410-7910.

[6] Miswanto dan Mat Safaat. 2018. Dampak Pembangunan Industri Pariwisata Terhadap Alih Fungsi Lahan. (Studi Tentang Kehidupan Sosial Budaya Masyarakat Desa Teluk Bakau, Kecamatan Gunung Kijang, Kabupaten Bintan, Kepulauan Riau). Jurnal Antropologi, Volume 20 (1), Juni 2018: 45-55 ISSN 1410-8356.

[7] Pendit, Ny. S. 1981. Ilmu Pariwisata. Jakarta: Pradnya Paramita.

[8] Pitana, I Gde, Gayatri, Putu G. 2005. Sosiologi Pariwisata. Yogyakarta: Andi Offset.

[9] Pramono, Heru. 1993. Dampak Pembangunan Pariwisata Terhadap Ekonomi, Sosial, dan Budaya. Cakrawala Pendidikan Nomor 1, Tahun XII.

[10] Richardson, John and Martin Fluker. 2004. Understanding and Managing Tourism. Australia: Pearson Education.

[11] Rencana Pembangunan Jangka Menengah Nasional 2015 - 2019 tentang Pemerataan Pembangunan Antar Wilayah Terutama Kawasan Timur Indonesia.

[12] Sessoms, L.D. 1984. Leisure Services. New Jersey: Prentice Hall, Inc.

[13] Spillane, J.J. 1987. Ekonomi Pariwisata, Sejarah, dan Prospeknya. Yogyakarta: Penerbit Kanisius.

[14] Spradley, James P. 1979. The Ethnography Interview. New York: Holt, Richart, and Winston.

[15] Thelisa, dkk. 2018. Pengaruh Pariwisata Terhadap Kondisi Sosial Budaya Masyarakat Karimun Jawa, Jawa Tengah. JUMPA Volume 4 Nomor 2.

[16] Wahab, Salah. 1975. Tourism Management. London: Tourism International Press. 